\title{
Theoretical Contribution of the Scientific Outlook on Development in the Context of Epidemic
}

\author{
Shilin Xu \\ Marx School, Lianyungang Normal College, Lianyungang, China \\ Email: 10902336@qq.com
}

How to cite this paper: Xu, S.L. (2021) Theoretical Contribution of the Scientific Outlook on Development in the Context of Epidemic. Open Access Library Journal, 8: e8110.

https://doi.org/10.4236/oalib.1108110

Received: October 22, 2021

Accepted: November 26, 2021

Published: November 29, 2021

Copyright () 2021 by author(s) and Open Access Library Inc.

This work is licensed under the Creative Commons Attribution International License (CC BY 4.0).

http://creativecommons.org/licenses/by/4.0/

\begin{abstract}
At present, the COVID-19 epidemic is still unfolding all over the world. In the face of the epidemic outbreak, all countries are trying their best to prevent the spread of the epidemic and reduce the harm brought by it. China has also taken a series of measures to effectively prevent and control the spread of the epidemic, and some achievements have been made in the prevention and control of the epidemic. And China is the only country in the world that has maintained economic growth during the pandemic. The experience of dealing with public health emergencies with the Scientific Outlook on Development is an important reference for China's epidemic prevention and control. The Scientific Outlook on Development under the background of the outbreak still has important meaning. The theme of the Scientific Outlook on Development is how to develop our country under the pressure of resources and environment. In the process of epidemic prevention and control, China has adopted policies and measures that fully reflect the core position of putting people first, and at the same time, it has promoted comprehensive, balanced and sustainable economic and social development by conducting unified planning and taking all factors into consideration.
\end{abstract}

\section{Subject Areas}

Politics

\section{Keywords}

Scientific Outlook on Development, Contemporary Theoretical Value, Contemporary Practical Value 


\section{Introduction}

The Scientific Outlook on Development puts development as the primary task; the principle of putting people first at the core; comprehensive, balanced and sustainable development as the basic requirement; and conducting unified planning, taking all factors into consideration as its the basic approach. The Scientific Outlook on Development is put forward in response to a series of challenges encountered in China's economic and social development at the beginning of this century. The formation of the Scientific Outlook on Development also contains the inspiration of the victory over SARS (Severe Acute Respiratory Syndrome). The Scientific Outlook on Development is not only of great significance to China's economic and social development at that time, but also of great theoretical and practical significance now.

\section{The Scientific Connotation and Main Content of the Scientific Outlook on Development}

The core of the Scientific Outlook on Development is people-oriented. The word "people-oriented" first appeared in the book Guan Zi. The word "peopleoriented" in the book reflects the civilian-oriented thought in Chinese traditional culture. The word "people" in the civilian-oriented thought refers to "subjects", however, the monarch and his subjects in the position were unequal in social status. It was impossible to be truly people-oriented. The people-oriented thought of the Scientific Outlook on Development is fundamentally different from the civilian-oriented thought of ancient China. Comrade $\mathrm{Hu}$ Jintao made a complete summary of the meaning of "people-oriented" in his speech at the seminar for members and alternate members of the new Central Committee to study and implement the spirit of the 17th National Congress of the CPC (Chinese Communist Party) in 2007: "By putting people first, we mean that we must serve the people wholeheartedly, build the CPC for the public interests and govern for the people, always make sure that the aim and outcome of all the work of the CPC and the state is the fundamental interests of the overwhelming majority of the people. We should uphold the consistency between respecting the law of social development and respecting the principal position of the people in history, between striving for lofty ideals and working for the interests of the overwhelming majority of the people, and between fulfilling the CPC's work and realizing the interests of the people. We will persist that development is for the people, by the people, and benefiting the people." ([1] p. 107) In addition, Comrade Hu Jintao also put forward in a number of speeches to adhere to the people-oriented thought, which can be seen from these speeches mainly includes the following contents: first, the people-oriented thought of the Scientific Outlook on Development, first of all, should be based on the fundamental interests of the overwhelming majority of the people. In 2004, when Comrade Hu Jintao visited Jiangsu Province, he pointed out that we should always put the fundamental interests of the overwhelming majority of the people in the first place, and con- 
stantly meet the needs of the people, serve the people with performing real deeds for them. Putting people first requires that everything we do must proceed from the interests of the overwhelming majority of the people, and that the interests of the overwhelming majority of the people are the starting point, objective and destination. Our party comes from the people, and more importantly, it must serve them. Second, the Scientific Outlook on Development puts people first and insists that the people are the force to rely on for development, because the broad masses of the people are builders of China's socialist cause and creators of material and spiritual wealth. The wisdom of the people is infinite. In socialist construction, we must "maximize the wisdom and strength of the whole society and the whole nation" ([2] p. 25) for socialist modernization with Chinese characteristics. In his speech at the 2003 National Conference on Talents, Hu Jintao stressed that talents are the most important resources, and we must respect talents and creation and give full play to the role of talents. Third, the result of development should be shared by the people, for the purpose of the socialist economic and social development is in order to meet the needs of the people, safeguard the economic, political and cultural rights and interests of the masses of the people. Fourth, the people-oriented thought of the Scientific Outlook on Development emphasizes that the development of the society is ultimately for the all-round development of individuals. The ultimate goal of social and personal development is the same. Developing productivity vigorously and improving people's material and cultural level are the basis of people's all-round development. The ultimate realization of people's all-round development is the real peopleoriented.

The first essence of the Scientific Outlook on Development is development, which is comprehensive, balanced and sustainable. Development is the key to solve all problems in our country. The first essence is that development is due to the basic reality that China is in the primary stage of socialism, to this end, "we must regard development as the top priority of the party in governing and rejuvenating the country" ([3] p. 143). Comprehensive, balanced and sustainable development mainly includes the following aspects: First, the development is comprehensive and balanced development. The first essence of the Scientific Outlook on Development is that development requires us to take economic construction as the center, but development is by no means only economic development. Development is a comprehensive and balanced development including economy, politics, culture, society and ecology. From the point of view of the domestic environment, at the beginning of this century, although our country after reform and opening up has made some achievements, we also came to the difficult and critical period of socialist construction in our country. Then some problem about comprehensive and balanced development appeared, such as economic development power. The extensive economic growth mode had not fundamentally changed. Increased pressure was on resources and the environment. Economic development was rapid, but social development was relatively 
backward. There was still a considerable gap between urban and rural areas and between different regions. Poor and low-income population was a considerable number, etc. In the domestic development environment, China's socialist construction was hard. At this time, the disadvantages of extensive economic growth pattern in our country gradually revealed. High input and high consumption growth led to the lack of natural resources, even seriously destroyed ecological balance. In this context, we must fully rely on science and technology to guide and lead the efficacy. We must rely on scientific and technological transformation of the mode of economic development. We must change from paying attention to the quantity of economic growth mode before to paying attention to the quality of economic development mode now. We must promote comprehensive, balanced and sustainable economic and social development. Second, scientific development is sustainable. Harmonious coexistence between man and nature is the core idea of sustainable development of the Scientific Outlook on Development. In 2004, in his speech at the Central Symposium on Population, Resources and Environment, Comrade Hu Jintao further clarified the connotation of the basic requirements for sustainable development of the Scientific Outlook on Development: "Sustainable development means to promote harmony between man and nature, to balance economic growth with population, resources and environment, to follow a path of civilized development featuring increased production, better living standards and a sound ecological environment, and to ensure sustainable development from generation to generation." ([3] p. 167) In the process of building a harmonious socialist society, "we should follow the general requirements of democracy and rule of law, equity and justice, stability and order, and harmonious coexistence between man and nature, and the principle of common construction and common enjoyment" ([3] p. 626). The 17th National Congress of the CPC clearly put forward the "construction of Eco-civilization", elaborated the goal of Eco-civilization construction, and put forward the construction of Eco-civilization as a strategic task clearly for the first time. Third, development should be tailored to local conditions, and different regional development models should be developed according to the characteristics of different regions. Different regions in China have different development environments, and some regions should pay more attention to ecological and environmental protection. Comrade Hu Jintao pointed out in his speech that Bijie should not copy the practices and models of the open coastal areas. Paying attention to ecological protection is of important strategic significance for the development of areas such as Guizhou, Xinjiang and Tibet. In 2010, while promoting Tibet's economic and social development, Comrade Hu Jintao pointed out: "Tibet special geographical natural conditions and economic and social conditions, not copying other local development pattern, especially can't find a way of governance after destruction first." ([4] p. 312)

The basic approach of the Scientific Outlook on Development is overall consideration. In the history of the CPC's development, Comrade Mao Zedong first 
used this idiom to summarize the "policy" that we should adhere to at that time, mainly referring to the guiding principles for adjusting the five economic components of the new democratic society. Later, Mao Zedong explained the "policy" of "overall consideration" for the first time in his book On the Correct Handling of Contradictions among the People. It refers to the guiding principle that should be adhered to when conflicts arise at that time. The interests of all the people should be taken into account when solving conflicts. The basic meaning of overall consideration in the Scientific Outlook on Development is quite different from that proposed by Mao Zedong. The difference lies in the strong directivity and particularity of overall consideration as a "policy". And overall consideration as a "basic approach", from the sense of methodology, is universal, more widely applicable than "policy". At the third Plenary Session of the 16th Central Committee of the CPC, the basic connotation of overall planning and taking into account as the basic approach was summarized, that is, "overall planning for urban and rural development, overall planning for regional development, overall planning for economic and social development, overall planning for harmonious development between man and nature, overall planning for domestic development and opening up to the outside world" ([5] p. 465). Then, the report to the 17th National Congress of the CPC greatly enriched and developed the basic connotation of overall planning. According to the report: "We need to correctly understand and properly handle the major relationships in the cause of socialism with Chinese characteristics, balance urban and rural development, regional development, economic and social development, relations between man and nature, and domestic development and opening-up. We must take into overall consideration the relationships between the central and local authorities, between personal and collective interests, between interests of the part and those of the all, and between immediate and long-term interests, so as to fully arouse to the initiative of all sides. We must take both domestic and international situations into consideration, develop a global and strategic perspective, and be good at seizing opportunities for development and coping with risks and challenges in a changing world, and work for a favorable international environment." ([6] p. 300) The basic connotation of "overall consideration" of the Scientific Outlook on Development not only "need to correctly understand and properly handle the major relationships in the cause of socialism with Chinese characteristics", but also need to focus on the major work affecting the overall situation and the prominent problems concerning the interests of the people. We should base ourselves on our national conditions. We must consider the overall situation and hold the key points. Overall consideration is a scientific working method that our party has always adhered to.

Therefore, from the above content analysis to the people-oriented thought, comprehensive, balanced and sustainable development, and overall consideration, we can see that the thought of comprehensive, balanced and sustainable development contains the basic approach of overall consideration. The thought 
of overall consideration also includes the thought of comprehensive, balanced and sustainable development. The thoughts of comprehensive, balanced and sustainable development and overall consideration all adhere to the people-oriented core position. These four core contents of the Scientific Outlook on Development are interrelated and integrated.

\section{Contemporary Theoretical Value of the Scientific Outlook on Development}

\subsection{The Contemporary Theoretical Significance of the People-Oriented Thought of the Scientific Outlook on Development}

The people-oriented thought of the Scientific Outlook on Development is a criticism of the western humanism. The "humanism" thought in the Renaissance carries out the theory of human nature and humanitarian spirit, opposes the supremacy of theocracy and believes in "I consider myself". Modern humanism pays more attention to individual living conditions and emotional will. Modern humanism has a wide influence in the western society. It has been integrated into the entire western social life, and become the mainstream values of the western society. It can be seen from the development of Western humanism that the western humanism thoughts are full of individual-centered thoughts. Western humanism opposes "theocracy", and at the same time goes to another extremeextreme individualism. It leads people to ignore the interests of others, collective and society. It will bring disastrous consequences to the whole society and even the world. People-oriented thought, as the core of the Scientific Outlook on Development, is different. The purpose of people-oriented thought is to pursue individual freedom, happiness and power, but this kind of personal freedom and happiness premises the development of the society as a whole. Only in a society where individuals truly achieve freedom and all-round development can individuals finally achieve true happiness.

The people-oriented thought of the Scientific Outlook on Development is the inheritance and development of Marx and Engels' humanistic theory. There are full of the people-oriented idea in Marx and Engels' classic works. Firstly, the thought of individual all-round development is the core of Marx and Engels' humanistic theory. Marx imagined that the communist society will be a comprehensive and free development of society where people can realize the real freedom. In addition, Marx for the first time established humanistic thought on the basis of historical materialism, and emphasized that the masses are the creators of history. But Marx and Engels' humanistic theory remained more in the stage of imagination, and they also did not explicitly put forward the "peopleoriented" thought. The people-oriented thought of the Scientific Outlook on Development makes Marx and Engels' humanistic thoughts have the realistic foundation. The people-oriented thought of the Scientific Outlook on Development was formed on the basis of the practical experience of the emergence of the stage 
characteristics of China's socialist society at that time. And it was the successful response to the international financial crisis and the victory over the sudden outbreak of SARS. It was formed from the domestic and international situation at that time and took the development of real people as the foothold and starting point. The Scientific Outlook on Development also emphasized that we should start from the fundamental interests of the majority of the people and we should rely on the masses to carry out socialist construction. The people-oriented thought is a realistic response to Marx and Engels' humanistic thought in the practice of building socialism with Chinese characteristics.

The people-oriented thought of the Scientific Outlook on Development is a further enrichment and development of the mass concept of Mao Zedong, Deng Xiaoping and Jiang Zemin. The Chinese Communists represented by Mao Zedong applied the principle that the masses are the creators of history into practice and formed the CPC's mass line. The mass line is the fundamental work route. First of all, it requires our "all for masses". The CPC must serve the people heart and soul, and act in the interests of the overwhelming majority of the people. "Three benefits" was proposed by Deng Xiaoping as a criterion for judging the success or failure of reform and all kinds of work. "Whether it is conducive to improving the people's living standard" was one of the criteria. Reform is for the people's interests. When summarizing the essence of socialism, Deng Xiaoping held that the ultimate goal of socialist development was to realize the common prosperity of all the people. The CPC must always represent the fundamental interests of the overwhelming majority of the Chinese people, which is one of the core views of the Theory of Three Represents. It is the starting point and foothold of the CPC's work. The Scientific Outlook on Development summarizes their thoughts about the people with the "people-oriented" thought and expresses them more succinctly. From the point of view of content, the peopleoriented thought also further enriches their thoughts. The Scientific Outlook on Development plays the role of linking the preceding and the following, and it is the source and theoretical basis of the people-centered approach to development. The people-centered approach to development is the foundation of Xi Jinping Thought on Socialism with Chinese Characteristics for a New Era. The peopleoriented thought is the direct ideological source of the people-centered approach to development. The people-centered approach to development adheres to and develops the people-oriented thought. The people-centered approach to development is the ideological development and theoretical sublimation of the peopleoriented thought in the new era.

\subsection{The Theoretical Value of Sustainable Development Thought of the Scientific Outlook on Development}

The sustainable development thought of the Scientific Outlook on Development absorbed the reasonable content of the western sustainable development theory in the last century. In the last century, the developed industrial civilization in the 
West brought rapid development and great wealth to the western society, while the ecological crisis also emerged. Some ecological disasters made people start to think about how human beings should develop, and the theory of sustainable development emerged at the historic moment. The main content of the sustainable development theory in the west is "development that meets the needs of the present without jeopardizing the ability of future generations to meet their own needs" ([7] p. 52)]. In 2002, a world summit for sustainable development in Johannesburg added the content of the poverty to the concept of sustainable development. But the sustainable development theory in the west only considers the intergenerational relationship and interpersonal relationships. Our development should not only take into account the interests of future generations, but also solve the pressing problems facing modern people. Failure to solve the development problems faced by modern people will inevitably affect the development of future generations. Moreover, although the sustainable development theory in the west proposes to solve the problem of poverty, it fails to see that the ecological crisis, resource shortage and other environmental problems faced by many developing countries are precisely caused by developed countries. Developed countries are responsible for them. The sustainable development thought of the Scientific Outlook on Development overcomes the deficiency of the sustainable development theory in the west. It is built on the people-oriented core position. It takes into account the relationship of the people, and it considers the relationship between human and natural resources, environment. We should achieve the harmony of man and nature and build an ecological civilization. On the basis of respecting the laws of nature, the all-round development of human beings and the all-round progress of society can be realized. Only in this way can the development needs of future generations be truly taken into account. When solving poverty in developing countries, the Scientific Outlook on Development emphasizes that both developed and developing countries should make joint efforts, and developed countries should also assume their own responsibilities.

The sustainable development thought of the Scientific Outlook on Development also contains the experience summary in China's socialist construction. The western industrial civilization was achieved through the continuous exploitation of resources and the endless plunder of nature. This development is not sustainable. The CPC's first generation of leaders had seen this point. However, because we were eager to catch up with other countries, it had brought us serious waste of resources and ecological destruction. Comrade Deng Xiaoping learned the lessons from China's construction in the early days of the founding of the People's Republic of China. He integrated environmental protection into the country's economic strategy. He had repeatedly stressed that our development should not be based on the model of treatment after pollution done by western countries. Therefore, Comrade Deng Xiaoping put forward a series of relevant environmental protection measures, and pointed out that the environmental protection to use science and technology for the first time. In terms of poverty 
eradication, Deng Xiaoping had always stressed that "poverty is not socialism, and socialism is to eradicate poverty" ([8] p. 116). Comrade Deng Xiaoping put environmental protection into practice. Jiang Zemin once again increased the protection of the environment and ecology from the concept and action. He introduced the western sustainable development concept into China, and began to implement the strategy of sustainable development. The idea of sustainable development of the Scientific Outlook on Development deepens the sustainable development strategy. The word "Eco-civilization" was clearly put forward for the first time in the report of the 17th CPC National Congress, and the construction of Eco-civilization was established as the guiding ideology of the construction of socialism with Chinese characteristics at the 18th CPC National Congress. The sustainable development of the Scientific Outlook on Development is not only considered from the relationship between man and ecology, but also the overall requirements of economy, politics, culture and society. Only by coordinating the relationship among economy, politics, culture, society and ecology on the whole can we maintain the harmonious relationship among social population, natural resources and ecological environment. Xi Jinping's thought on Ecolcivilization enriched and developed the sustainable development thought of the Scientific Outlook on Development, and proposed that "the modernization we want to build is the modernization of harmonious coexistence between man and nature" ([9] p. 40). Xi Jinping's thought on Eco-civilization further sublimated the sustainable development idea of the Scientific Concept of Development.

\subsection{The Theoretical Value of the Basic Approach of Overall Consideration}

The basic approach of overall consideration based on China's reality is the concrete embodiment of the basic view of Marxist materialist dialectics in contemporary China. However, in the history of the development of Marxism, Marx and Engels did not directly discuss the overall consideration as a methodological significance. After the October Revolution, Lenin took into account some considerations in dealing with the socialist public ownership economy and other coexisting economic forms. But these ideas are different from China's overall consideration. The basic approach of China's overall consideration is the sinicized Marxist methodology. In Our country, Comrade Mao Zedong did not summarize the meaning of overall consideration, nor did he specifically describe the content of the policy of overall consideration. Deng Xiaoping did not explicitly mention overall consideration. But a series of ideas of "a two-pronged approach" proposed by Deng Xiaoping, as well as the thought of coordinating the development relationship between coastal and inland areas, are the embodiment of overall consideration. When talking about overall consideration, Jiang Zemin pointed out that "the interests of the state, the collective and the individual should be taken into account as a whole, and the distribution relationship between the state and enterprises, the central and local governments should be straigh- 
tened out" ([10] p. 229). And "the coordinated development of economy, society and the environment should be taken into account as a whole" ([11] p. 446). Although these ideas are also scattered, they expand the content of overall consideration as a working method and become a direct source of ideas for the basic approach to overall consideration. On the basis of Mao Zedong's, Deng Xiaoping's and Jiang Zemin's thoughts, the overall consideration of the Scientific Outlook on Development is further developed and perfected. The basic approach of overall consideration is also more complete, because in the scientific connotation of the Scientific Outlook on Development, apart from clearly proposing that "overall consideration is the basic approach", there are also three contents. And this basic approach is a whole with the other three contents. The overall consideration is for the purpose of development, is to adhere to the peopleoriented core position, and the basic requirement is comprehensive, balanced and sustainable. The four aspects complement each other. The thought of overall consideration of the Scientific Outlook on Development and the thought of overall consideration contained in Xi Jinping Thought on Socialism with Chinese Characteristics for a New Era are closely linked. The former is the development foundation of the latter, which further enriches the former. On the basis of the thought of overall consideration of the Scientific Outlook on Development, Comrade Xi Jinping proposed in the report of the 19th National Congress of the CPC that "overall consideration of development and security" should be taken into account. The thought of overall consideration of development and security is a further deepening of the overall consideration of the Scientific Outlook on Development.

\section{Contemporary Practical Value of the Scientific Outlook on Development}

\subsection{Paying Attention to Ecology and Green Development}

The Scientific Outlook on Development has answered the major questions of what kind of development we should achieve and how we should achieve it under the new circumstances. It has also provided important reference for how we should achieve development in the face of public health emergencies and major natural disasters. SARS broke out in China in 2003. An important lesson from the fight against SARS is that "in the process of promoting development, we should not only pay attention to economic indicators, but also pay attention to cultural, resource and environmental indicators. We need to increase input not only in promoting economic growth, but also in promoting social development and protecting resources and the environment" ([2] p. 30)]. The formation of the Scientific Outlook on Development contains the experience of dealing with the SARS epidemic, which is not only a summary of our experience in dealing with emergencies, but also the basic requirements for the development of our country. Scientific development is not only economic development, but also comprehensive social progress. It is the comprehensive economic, political, cultural, 
social and ecological development. Therefore, in the process of epidemic prevention and control, we should not relax economic recovery and development, but also take into account the comprehensive social development and progress. In addition, we also summarized the experience of preventing natural disasters in the 2008 earthquake relief struggle, that is, "to develop and utilize nature, we should first understand nature, respect nature, and act in accordance with the laws of nature" ([4] p. 135). Scientific development should be a sustainable and coordinated development and a harmonious development between man and nature. Now we have to deal with the global environmental problems. The countermeasures of the sustainable development thought of the Scientific Outlook on Development to the climate change at that time are still instructive to the reality. We need to rely on China's development to cope with ecological problems. We need to vigorously develop a low-carbon economy and circular economy, advocate green living, build a resource-conserving and environment-friendly society, and build an ecological civilization.

\subsection{People's Interests Be Put First in Epidemic Prevention and Control}

When dealing with the SARS epidemic, Comrade Hu Jintao pointed out that "We must take the prevention and treatment of SARS as a major issue concerning the health and safety of the people and the overall situation of reform, development and stability, and pay close attention to it" ([3] p. 22). This is precisely why we regard the fundamental interests of the overwhelming majority of the people as the fundamental starting point and goal of the work of the CPC and the state, and always put the interests of the people first. In addition, in the prevention and treatment of SARS, the relationship between the prevention and treatment of SARS and the promotion of economic development should be properly handled. We should not relax economic construction while preventing and treating SARS because only by promoting economic development can we ensure sufficient financial and material resources to prevent and control the epidemic, ensure the production and living needs of the people, provide a material basis for social stability, and truly guarantee the interests of the people. To solve the problem of epidemic prevention and control, we must rely on development. The experience of fighting the SARS epidemic provides an important reference for China's current fight against the COVID-19 (Corona Virus Disease 2019) epidemic. In the fight against COVID-19, General Secretary Xi Jinping has stressed on many occasions that "people's life and health should come first" [12], and the interests of the people are the starting point and foothold of all work. The government has taken the policy of paying all the medical expenses of COVID-19 patients to ensure the safety of people's lives and health first. While fighting the epidemic, China can resume work and production conditionally. Practice has proved that China can maintain economic growth during the epidemic, which has laid a strong material foundation for good social order. 
And the benign development of economy and society guarantees the success of vaccine research and development in China. The success of vaccine development is conducive to epidemic prevention and control, which in turn promotes economic development and realizes a virtuous circle of economic and social development. When the vaccine is successfully developed, with the material guarantee of economic development, China has implemented the policy of free vaccination for the masses, which fully reflects that development is the key to solve all problems.

\subsection{Relying on the Masses and Drawing Wisdom from the Masses in Epidemic Prevention and Control Practices}

In the face of the epidemic, what we need to do is to focus on the overall situation and solve the problems in China's socialist economic, political, cultural, social and ecological progress. This requires us to rely on the people, adhere to the basic principle of putting people first, and pool the wisdom and strength of the whole society and nation to fight the epidemic and build socialism with Chinese characteristics. From the time of the war, the masses of the people have always been our strong strength to rely on. In the fight against the SARS epidemic, under the leadership of the CPC and the people's government, we fully relied on the people, mobilized them, coordinated the interests, relations and resources of all sectors, and relied on the strength and wisdom of the people. We also won the victory against the SARS epidemic, which also provides inspiration for the fight against the COVID-19 epidemic. Relying on the strength of the masses, Wuhan Huoshenshan Hospital and Leishenshan Hospital could be built quickly and efficiently. The rapid construction of the two hospitals greatly improved the treatment capacity of local hospitals. Behind this "Chinese speed" is the wisdom and sweat of tens of thousands of people. China's achievements in epidemic prevention and control could not have been achieved without the concerted efforts of the people at the grass-roots level, especially with the wisdom and strength of the community. The community made people know how to prevent and control the virus through publicity, met the basic living needs of people quarantined at home through delivery services, implemented risk control of the epidemic in the community, and effectively blocked the spread of the virus by tracking cases. In the fight against the epidemic, the wisdom of the masses has been fully demonstrated. When the epidemic was severe and supplies were in short supply, people came up with ingenious measures to prevent the spread of the virus. In the resumption of work and production, the wisdom of the people has been brought into play. People have made full use of available resources to try every means to resume work and production, which has led to steady economic recovery and growth. In the fight against the epidemic, China has always put people first, relied on the people, gave play to their wisdom and strength, pooled their wisdom, and mobilized all forces of the whole society for joint prevention and control. Practice has proved that this is the best way to deal with the epi- 
demic.

\subsection{Adhering to the Basic Approach of Overall Consideration Consistently in the Construction of Socialism with Chinese Characteristics}

At the beginning of this century, the basic approach of overall consideration was put forward. It was the fundamental method to correctly understand and deal with a series of challenges encountered in socialist modernization. The basic approach of overall consideration viewed development as a coordinated process, and it strived to achieve harmony between the economy and society, and between man and nature. By adhering to the basic approach of overall consideration, China has overcome a series of development challenges at the beginning of this century, consolidated and developed China's socialist modernization drive, and paved the way for China to complete the building of a moderately prosperous society in all respects. The basic approach of overall consideration is the scientific methodology we have always adhered to, and we still need to take all factors into consideration in our socialist modernization drive with Chinese characteristics in the new era. In building socialism with Chinese characteristics in the new era, there are still many major relations. Although the characteristics of these major relations have changed over time from those at the beginning of this century, we must still adhere to the basic approach of overall consideration to handle these major relations. In terms of economic construction, China persists in actively promoting supply-side reform, accelerating the development of advanced manufacturing, implementing the innovation-driven development strategy, improving the efficiency of resource utilization, and effectively alleviating the pressure on resources and the environment. In terms of social development, we will continue to win the battle against poverty and eliminate poverty, with the focus on the rural population. This year, China has lifted itself out of poverty. Through the rural revitalization strategy, China's rural areas are developing rapidly and the gap between urban and rural areas is narrowing. On the coordinated development between regions, China will continue to adhere to the original strategy of developing the western region, revitalizing the northeast and rising the central region. In addition, China has actively promoted the coordinated development of the Beijing-Tianjin-Hebei region, the development of the Yangtze River Economic Belt, the development of the Guangdong-Hong Kong-Macao Greater Bay Area and the integrated development of the Yangtze River Delta. We will actively promote balanced development among regions. In international affairs, China is committed to an independent foreign policy of peace and actively promotes to build a global community with a shared future. China's contribution to the world economy is increasing, especially through the Belt and Road Initiative to promote common development of neighboring countries. By taking into account the overall situation and focusing on key areas, China's socialist construction has yielded fruitful results. 


\subsection{Using the Basic Approach of Overall Consideration to Deal with Social Emergencies}

Modern society is a risk society. After the west the one-sided emphasis on the development of the economic growth pattern, nature and human beings are threatened by the irresistible. And with the development of globalization, this kind of crisis spreads to the whole world, which is manifested by the increase of sudden risks faced by all countries, public health emergencies being one of them. In the face of the sudden outbreak, China has learned an important lesson in COVID-19 prevention and control by adopting the basic approach of overall consideration. First, epidemic prevention and control should be coordinated with economic and social development. In the process of epidemic prevention and control, China has not only resumed work and production, but also maintained a stable social order. At the same time, China has achieved the set goal of poverty alleviation and building a moderately prosperous society in all respects. In addition to the coronavirus pandemic, our economy has grown in a time of economic recession in most countries. This has also promoted our scientific and technological innovation, ensured the successful development of COVID-19 vaccine, and provided strong material guarantee for the effective fight against the epidemic. Secondly, in the process of epidemic prevention and control, the relationship between individual interests and collective interests, local interests and overall interests, as well as current interests and long-term interests should be taken into consideration. When COVID-19 spreads in western countries, the public in western countries shows a very negative attitude towards the control of the epidemic and opposes the government's policies and measures to control the virus, which reflects the strong values of individualism among the people in western countries. In socialist society, personal interests and social and collective interests in the root is consistent. In the process of epidemic prevention and control, the Chinese people actively responded to the call of the country, stayed at home when the epidemic was serious and actively cooperated with the epidemic prevention work. People can put the collective interest, the overall interest and the long-term interest first. When individual interests conflict with collective interests, individual interests should be subordinated to collective interests. Finally, we need to balance the overall domestic and international situation. China has achieved very good results in epidemic prevention and control, fully showing the advantages of China's socialist system. From the perspective of current epidemic prevention and control, the biggest threat facing China's epidemic prevention and control is the importation of foreign cases. Despite the achievements made at home, China is also actively working with other countries to fight the virus. On the one hand, China has actively promoted its successful experience in epidemic prevention and control, and on the other hand, announced that China's successful vaccine development will be shared by all mankind. This fully shows that China can take into account both the domestic and international situations, and China is a responsible and responsible major country. 


\section{Conclusion}

The Scientific Outlook on Development is a long-term guiding ideology that must be adhered to in developing socialism with Chinese characteristics. The Scientific Outlook on Development mainly criticized the Western humanism thought and the theory of sustainable development. It is the concentrated embodiment of the Marxist thought on development, the continuation and development of socialist theories with Chinese characteristics, and the development basis and theoretical source of Xi Jinping Thought on Socialism with Chinese Characteristics for a New Era. The Scientific Outlook on Development requires paying attention to ecology and green development. People's interests should be put first in epidemic prevention and control, and economic development should be promoted at the same time. The people-oriented thought of the Scientific Outlook on Development calls for relying on the masses and drawing wisdom from the masses in epidemic prevention and control practices. The basic approach of overall consideration is the methodology consistently adhered to in the construction of socialism with Chinese characteristics. It is our experience to use the basic approach of overall consideration to deal with social emergencies. In addition, the four aspects of the Scientific Outlook on Development are closely related to each other, and there is less discussion on the relationship between the four core contents of the Scientific Outlook on Development, which will be strengthened in the future.

\section{Conflicts of Interest}

The author declares no conflicts of interest.

\section{References}

[1] (2009) Selected Literature since the 17th National Congress of the CPC (I). Central Party Literature Press, Beijing.

[2] (2008) An Important Discussion on the Scientific Outlook on Development. Central Party Literature Press/Party Building Reading Press, Beijing.

[3] (2016) Selections from Hu Jintao: Volume II. People's Publishing House, Beijing.

[4] (2016) Selections from Hu Jintao: Volume III. People's Publishing House, Beijing.

[5] (2005) Selected Literature since the 16th National Congress of the CPC (I). Central Party Literature Press, Beijing.

[6] (2008) The Activities of In-Depth Study and Practice of the Scientific Outlook on Development, and the Selected Literature from Leading Cadres Studying Documents. Central Party Literature Press/Party Building Reading Press, Beijing.

[7] WCED, Wang, Z.J. and Ke, J.L. (1997) Our Common Future. Jilin People's Publishing House, Changchun.

[8] (1993) Selections from Deng Xiaoping: Volume III. People's Publishing House, Beijing.

[9] (2017) Documents of the 19th National Congress of the CPC. People's Publishing House, Beijing.

[10] (2006) Selections from Jiang Zemin: Volume I. People’s Publishing House, Beijing. 
[11] (2006) Selections from Jiang Zemin: Volume II. People's Publishing House, Beijing.

[12] Xi, J.P. (2020) Building a Strong Public Health System to Provide a Strong Guarantee for People's Health. Qiu Zhi, 10, 4-7. 